\title{
Study of the Role of Ethnicity in the Pathophysiology of Preeclampsia: A Prospective Observational Study in a Rural Hospital in India
}

\author{
Indranil Banerjee ${ }^{1 *}$, Archana Kumari ${ }^{2}$, Gargi Mukherjee ${ }^{1}$ \\ ${ }^{1}$ Basildon \& Thurrock University Hospital, Basildon, UK \\ ${ }^{2}$ Medical College, Kolkata, India \\ Email: ^indranil_md@yahoo.com
}

How to cite this paper: Banerjee, I., Kumari, A. and Mukherjee, G. (2021) Study of the Role of Ethnicity in the Pathophysiology of Preeclampsia: A Prospective Observational Study in a Rural Hospital in India. Open Journal of Obstetrics and Gynecolo$g y, 11,978-1004$.

https://doi.org/10.4236/ojog.2021.118093

Received: February 23, 2021

Accepted: August 10, 2021

Published: August 13, 2021

Copyright $\odot 2021$ by author(s) and Scientific Research Publishing Inc. This work is licensed under the Creative Commons Attribution International License (CC BY 4.0).

http://creativecommons.org/licenses/by/4.0/

\begin{abstract}
Hypertensive disorders (HD) of pregnancy are a leading cause of maternal and perinatal mortality and morbidity worldwide. Although several risk factors for hypertensive disorders of pregnancy have been firmly established, the risk attributable to specific race-ethnicities is less clear. The risk of preeclampsia-eclampsia may differ by maternal ethnicity 30 as also the course, severity and prognosis. This study aimed to compare severe preeclampsia and eclampsia in tribal and nontribal women of Jangalmahal area of West Bengal in terms of incidence, clinical, demographic picture, severity, course of disease, response to treatment, complications and delivery outcome including foetal outcome and maternal outcome.
\end{abstract}

\section{Keywords}

Ethnicity, Pre Eclampsia, Tribal

\section{Introduction}

Hypertensive disorders (HD) of pregnancy constitute a perplexing and clinically challenging group of complications of pregnancy and are responsible for a substantial burden of illness. They are a leading cause of maternal and perinatal mortality and morbidity worldwide, but especially in developing countries [1].

Preeclampsia is a multisystem disorder of unknown aetiology characterized by development of hypertension with proteinuria after $20^{\text {th }}$ week of gestation, in previously normotensive and non proteinuric pregnant women [2] [3]. 
Preeclampsia when complicated with generalized tonic-clonic convulsions and/or coma is called Eclampsia [4].

Globally HD of pregnancy complicate approximately 5\% - 10\% of pregnancies [5] [6] [7]. The incidence of preeclampsia and the precursor of eclampsia, vary greatly worldwide. Preeclampsia complicates about $2 \%-8 \%$ of all pregnancies [7] [8].

WHO estimates the incidence of preeclampsia to be seven times higher in developing countries ( $2.8 \%$ of live births) than in developed countries $(0.4 \%)$ which is due to poor health seeking behaviours and lack of availability of health care facilities and personnel [9].

Incidence of HD of pregnancy in India is found to be 11,266 out of 111,725 deliveries (10.08\%) as observed through the data collected by the National Eclampsia Registry (NER) over 3 years (2011-2013) [10]. Two thousand five hundred fifty-four of those 11,266 patients presented with eclampsia [10]. The FOGSI-ICOG NER has brought forth some revealing trends. Eclampsia prevalence among registry patients is $1.9 \%$ [10]. National sample surveys in the past have shown prevalence to be $1 \%-5 \%$. This is out of the 11,725 deliveries analyzed from the cases reported by 175 reporting centers. Seventeen percent of preeclampsia patients are actually in the adolescent age group reflecting the very early age at marriage in spite of several awareness programs and legal guidelines [10]. 76.34\% of the patients were between 21 and 30 years of age thus rendering a very young population morbid and at risk of mortality. It is also a disease of the first-time pregnant woman as $81 \%$ of the patients with preeclampsia are primigravida [10].

Approximately 72,000 pregnant women die every year because of eclampsia and severe preeclampsia worldwide [10]. HD account for $16 \%$ of all maternal deaths in developed countries [11]. The risk that a woman in a developing country will die of preeclampsia or eclampsia is about 300 times that of a woman in a developed country [12] [13] [14].

Reliable statistics about women dying due to preeclampsia-eclampsia are difficult to obtain because of the poor quality of vital statistics registration systems and hospital records in many developing countries. In addition, a sizable number of deliveries take place at home, and thus there are no records at all for these births [15] [16] [17] [18]. Therefore, data on women who die from preeclampsia-eclampsia are only available from a limited number of countries. Nevertheless, it is clear that the case fatality rates for preeclampsia-eclampsia vary greatly across countries, with the risk of death from preeclampsia-eclampsia being much higher in developing countries than in developed ones [19]. India is among those countries which have a very high MMR, i.e. 190 per 100,000 live births [20]. Hypertension accounts for 5\% of maternal deaths in India [21].

$\mathrm{HD}$ is also associated with preterm birth, foetal growth restriction, perinatal death and long-term adult health problems in the offspring. Preeclampsia causes five fold increase in the perinatal mortality, with most of the deaths caused by 
iatrogenic prematurity [22] [23]. In US, preeclampsia is responsible for $15 \%$ of premature births [24].

If the disorder occurs in early pregnancy, $53 \%$ of the infants are small for gestational age (SGA) [25]. Further, to be born SGA increases the risk of hypertension, diabetes and coronary heart disease as adults [26].

The risk of delivery of low birth weight (LBW) or growth-restricted babies in mothers with HD differs in different ethnic/racial groups [27] [28].

However, the causes for preeclampsia-eclampsia remain unclear and thus preeclampsia-eclampsia has been called a "Disease of theories" [29]. Almost everyone (from an allergist to zoologist) had proposed a theory and almost anything on the earth (from watermelon season to a specific worm infestation) has been blamed [30] [31]. Although the precise cause is unknown, the pathophysiologic processes underlying this disorder are described in two stages [32]. The first stage is characterized by reduced placental perfusion possibly related to abnormal placentation with impaired trophoblast invasion and inadequate remodeling of the uterine spiral arteries. The second stage refers to the maternal systemic manifestations with inflammatory, metabolic, and thrombotic responses converging to alter vascular function which can result in multi-organ damage [33] [34] [35].

Some risk factors for HD of pregnancy has been identified and these include nulliparity, older maternal age, multiple births, diabetes, chronic hypertension, obesity, previous h/o preeclampsia, family history of preeclampsia, a new partner and/or about 10 years since last pregnancy, renal disease, and the presence of antiphospholipid antibodies [7] [33] [36]-[43]. Studies have reported a 7\% - 20\% chance of recurrence of preeclampsia in a subsequent pregnancy [40] [44] [45].

Some other risk factors are still being investigated. Geographic, social, economic and racial differences are thought to be responsible for incidence rates up to 3 times higher in some populations [46].

Some studies have investigated racial and ethnic factors and identified some differences in severe preeclampsia and eclampsia in different population groups [18] [47] [48] [49] [50]. Among the major ethnic groups considered, East Asian women had the lowest risk of preeclampsia and Mexican women had the highest risk [47].

Caughey reported that the rates of preeclampsia were higher among African American women and lower among Latina and Asian women with all results being statistically significant as compared with white women [48]. Marcelo reported that immigrant women from the Caribbean, Sub-Saharan Africa and Hispanic America were at the highest risk of serious preeclampsia relative to immigrant women from industrialized nations [49]. In a study by Abubakar, among three tribal groups, the preeclamptic Fulani women are more likely to progress to eclampsia than the Hausa and Kanuri [18]. Black women were more likely to be diagnosed with preeclampsia than were White women [50]. The risk of preeclampsia-eclampsia may differ by maternal ethnicity [48] as also the course, se- 
verity and prognosis [18] [51] [52]. Such differences in severe preeclampsia and eclampsia in different ethnic population groups may also exist in India. But studies focussing on such aspects of preeclampsia and eclampsia in different population groups in India are scarce in literature. Ethnicity reflects many potential influences on health, including socioeconomic status, lifestyle (e.g. diet and physical activity), medical care utilization, and genetic background associated with geographic origin. Examining the relation of ethnicity with preeclampsia-eclampsia may provide important information that may highlight ethnic subgroups which need to be monitored more actively and could help guide screening and treatment, particularly in light of ethnic diversity of pregnancies [47].

\section{Aims and Objectives}

The objectives of this study were to note whether any differences existed among tribal and nontribal women with severe preeclampsia and eclampsia in the Jangalmahal area of West Bengal due to different ethnicity in the following parameters:

- Incidence.

- Clinical and demographic picture.

- Severity and course of disease.

- Response to treatment and complications.

- Delivery outcome including foetal and maternal outcomes.

Specific Objective:

To identify the ethnic/racial group at higher risk of severe preeclampsia and eclampsia among tribal and nontribal women.

\section{Materials and Methods}

\subsection{Study Area}

The present study was conducted in The Department of Obstetrics \& Gynaecology, Midnapore Medical College \& Hospital, Paschim Midnapore, West Bengal. (The area concerned has got a huge tribal population).

\subsection{Study Period}

The period of study was 1 year ( $1^{\text {st }}$ May, 2014 to $30^{\text {th }}$ April, 2015).

\subsection{Study Population and Sample Size}

Two hundred consecutive mothers coming from Jangalmahal area and admitted to the Obstetrics \& Gynaecology Department, Midnapore Medical College \& Hospital, Paschim Midnapore with severe preeclampsia and eclampsia were included in the study.

The mothers were divided into two groups:

1) Tribal Group (T group)

2) Nontribal Group (NT group). 


\subsection{Study Design}

The study was a prospective observational comparative study.

\subsection{Criteria for Sample Selection}

\section{Inclusion criteria:}

Mothers coming from Jangalmahal area of West Bengal and admitted to the Department of Obstetrics \& Gynaecology, Midnapore Medical College \& Hospital with severe preeclampsia and eclampsia were included in the study (BP $>160$ systolic and 110 diastolic along with UPCR $>30$ or Eclamptic fits).

\section{Exclusion criteria:}

- Women with gestational ages of less than 20 weeks.

- Pre-existing chronic hypertension/eesential hypertension.

- Pre-existing diabetes.

- Chronic renal disease (Q3).

\subsection{Parameters to Be Studied}

The study was conducted to compare whether any differences exist in cases of severe preeclampsia and eclampsia among tribal and nontribal women of the Jangalmahal area of West Bengal in the following parameters:

1) Incidence, clinical and demographic picture, severity and course of disease.

2) Response to treatment and complications.

3) Delivery outcome including foetal outcome and maternal outcome.

\subsection{Study Tool}

A detailed tool (case proforma) was developed and used to record data (observations) of each case as detailed in methods.

The data of individual patient was collected from the BHTs of patients, investigation reports, labour room records (Logbook), OT records and referral papers where applicable.

\subsection{Study Technique}

The study was approved by the Ethics Committee of our institution. It was conducted in the Dept. of G \& O, M.M.C. \& H. Two hundred consecutive mothers coming from Jangalmahal area and admitted to the G \& O Department, M.M.C. $\& \mathrm{H}$. with severe preeclampsia and eclampsia were enrolled in the study following the inclusion and exclusion criteria.

Pregnant women admitted in the labour room and meeting the inclusion criteria were selected after informed consent in the local language. The mothers included in the study were divided into two groups: Tribal (T) group \& Non tribal (NT) group.

Maternal ethnic ancestry was identified by self-report as recorded on the birth records and also the surnames which come under tribal groups were obtained from the District Magistrate's office. 
Severe preeclampsia was diagnosed [53] if a preeclamptic mother had blood pressure $\geq 160 / 110 \mathrm{mmHg}$ or proteinuria $\geq 3+$ or any of the following features: Headache, vomiting, clouding (blurring) of vision/blindness, oliguria (passing less than $400 \mathrm{ml}$ urine in $24 \mathrm{hrs}$ )/anuria, upper abdominal pain (epigastric pain or pain in the right upper quadrant), pulmonary oedema, hyperreflexia, HELLP syndrome.

Eclampsia was diagnosed if there was convulsion and/or coma with features of preeclampsia [53].

\subsection{Treatment Strategy}

All the patients received standard management (which was being followed in the institution) as follows:

1) Antihypertensives: Inj. Labetalol (10 mg) i.v. were given to the patients with blood pressure $>150 / 100 \mathrm{mmHg}$ and then repeated if necessary with incremental doses of $20 \mathrm{mg}, 40 \mathrm{mg}$ and $80 \mathrm{mg}$ at 10 mins interval [53] titrating according to blood pressure. Our goal was to maintain blood pressure between 140/90 - 150/100 mmHg.

2) Anticonvulsant: Inj. Magnesium sulfate is the drug of choice for preventing and treating convulsions in severe preeclampsia and eclampsia [53] [54]. It was given following Pritchard Regimen which is as follows [53] [54].

- LOADING DOSE: Magnesium sulfate 20\% solution 4 gm i.v. over 5 mins followed immediately by $10 \mathrm{gm}$ of $50 \%$ magnesium sulphate solution ( $5 \mathrm{gm}$ in each buttock) as deep i.m. injection with $1 \mathrm{ml}$ of $2 \%$ lignocaine in the same syringe.

- MAINTENENCE DOSE: 5 gm $\mathrm{MgSO}_{4}$ (50\% solution) plus $1 \mathrm{ml}$ lignocaine $2 \%$ i.m. every 4 hrs into alternate buttocks continued till 24 hrs after delivery or the last convulsion whichever occurs last.

Each maintenance dose was administered after ensuring that:

- Urinary output was at least $30 \mathrm{ml} / \mathrm{hr}$ which is equivalent to $100 \mathrm{ml}$ over 4 hours [53] (approx).

- Respiratory rate was at least $16 / \mathrm{min}$.

- Patellar reflex was present.

3) Termination of pregnancy: Mode \& method of termination was decided as per merits of individual cases with the aim of prompt and safe delivery.

On admission, in each case the demographic profile of the mother (age, parity, socioeconomic status etc.), gestational age, foetal condition, maternal condition on admission, whether in labour or not, stage phase of labour (if in labour) and any complication were noted. The initial choice for mode of delivery was also noted.

Investigations included urine analysis for albumin, blood for urea, creatinine, uric acid, Liver Function Tests, Hb\%, TC, DC, ESR \& platelet count and USG, CT scan \& MRI in selected cases. The results were noted.

Mothers were monitored for general conditions, progress of labour, complica- 
tions if any, response to treatment (blood pressure \& fits control, dose requirement of antihypertensives \& anticonvulsants).

Delivery outcomes including mode of delivery, foetal \& maternal outcomes were recorded. All the informations/observations from each patient were recorded in the study tool (proforma).

\subsection{Plan for Analysis of Data}

Data so collected was collated and analysed with appropriate statistical tests and methods.

Test of significance of difference was done by Student's two-tail " $t$ "-Test. $\mathrm{P}$ values less than 0.05 was considered as significant difference. Data were presented in tabular form and also represented by bar diagrams wherever needed. Data were expressed as Mean \pm Standard error of mean (SEM). Softwares used: Microsoft excel, SPSS version 19; Origin Lab (Ver 8.0) and MedCalc (Ver 6.2).

\subsection{Results and Analysis}

A total of consecutive 200 mothers, from Jangalmahal area, admitted to the Gynaecology \& Obstetrics Department of Midnapore Medical College \& Hospital with severe Preeclampsia and eclampsia were included in this study. Of these 200 mothers there were 65 mothers in Tribal (T) group and 135 mothers in Nontribal (NT) group. Of them 133 mothers had severe preeclampsia and 67 mothers had eclampsia. During the study period a total of 3768 (576 tribal and 3192 nontribal) women delivered in our institution. Thus, during the study period the overall incidence of severe preeclampsia and eclampsia in our institution were $3.53 \%$ and $1.78 \%$ respectively. Both severe preeclampsia and eclampsia were found to be significantly ( $\mathrm{p}<0.001$ ) more common in the T group than the NT group $(7.29 \%$ vs. $2.85 \%$ and $3.99 \%$ vs. $1.38 \%$ respectively (Table $1 \&$ Figure $1)$.

Both severe preeclampsia and eclampsia were found to be significantly $(\mathrm{p}<$ $0.001)$ more common in the tribal group than the nontribal group $(7.29 \%$ vs. $2.85 \%$ and $3.99 \%$ vs. $1.38 \%$ ) respectively.

In both tribal and nontribal groups, majority of mothers with severe preeclampsia and eclampsia were under 25 years of age. In comparative analysis, the tribal mothers exhibited a significant $(\mathrm{p}<0.05)$ higher percentage for age group of $\leq 20$ years and lower percentage for age group of $21-25$ years than that of nontribal mothers. The difference was insignificant $(\mathrm{p}>0.05)$ for the age group 26 - 30 years. Frequency of suffering subjects in age groups of 31 - 35 years

Table 1. Incidence of severe preeclampsia and eclampsia in Tribal and Nontribal mothers.

\begin{tabular}{ccc}
\hline Hypertensive disorder of pregnancy & $\mathrm{T}(\mathbf{n}=\mathbf{5 7 6})$ No. (\%) & NT $(\mathbf{n}=\mathbf{3 1 9 2})$ No. (\%) \\
\hline Severe preeclampsia & $42(7.29)$ & $91(2.85)$ \\
Eclampsia & $23(3.99)$ & $44(1.38)$ \\
\hline
\end{tabular}




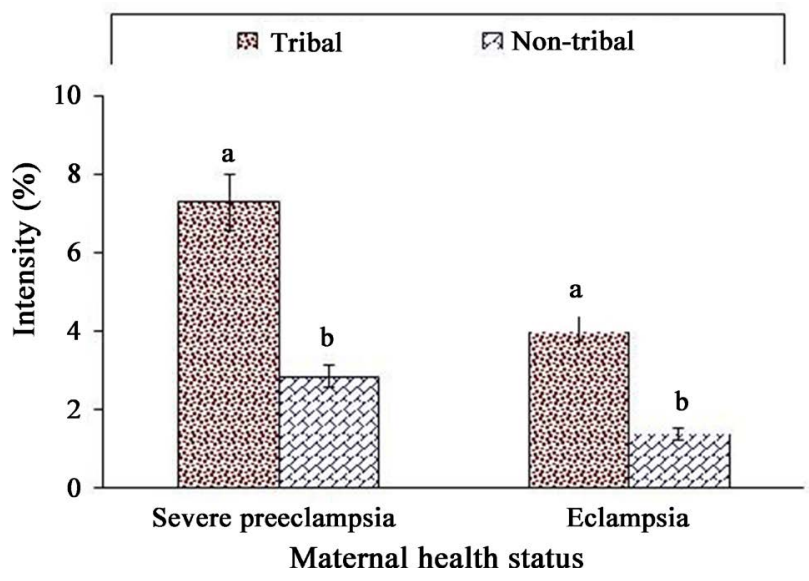

Figure 1. Incidence of severe preeclampsia and eclampsia in Tribal and Nontribal mothers. (Each bar represents Mean \pm SEM. Comparative analysis performed by two-tail " $t$ " test for means. Bars with different superscripts $(a, b)$ differ from each other significantly at the level of $\mathrm{p}<0.001$.)

Table 2. Age wise distribution of severe preeclampsia and eclampsia in Tribal and Nontribal group.

\begin{tabular}{ccc}
\hline & Tribal $(\mathbf{n}=65)$ & Nontribal $(\mathbf{n}=135)$ \\
\cline { 2 - 3 } Age (Years) & \multicolumn{2}{c}{$\%$} \\
\hline 20 & $70.77 \pm 2.38^{\mathrm{a}}$ & $64.44 \pm 2.13^{\mathrm{b}}$ \\
$21-25$ & $21.54 \pm 1.32^{\mathrm{a}}$ & $25.93 \pm 1.29^{\mathrm{b}}$ \\
$26-30$ & $6.15 \pm 1.19^{\mathrm{a}}$ & $8.15 \pm 1.13^{\mathrm{a}}$ \\
$31-35$ & $0 \pm 0.00^{\mathrm{a}}$ & $1.48 \pm 0.89^{\mathrm{b}}$ \\
$>35$ & $1.54 \pm 0.11^{\mathrm{a}}$ & $0 \pm 0.00^{\mathrm{b}}$
\end{tabular}

(Data were expressed as Mean \pm SEM in percentage value. Values of each row with different superscripts (a, b) differ from each other significantly $(\mathrm{p}<0.05)$ ).

Table 3. Parity wise distribution of mothers in Tribal and Nontribal groups.

\begin{tabular}{ccc}
\hline Parity & $\mathrm{T}(\mathrm{n}=65)$ No. (\%) & NT $(\mathrm{n}=135)$ No. (\%) \\
\hline Nullipara & $56(86.15)$ & $108(80)$ \\
Primipara & $7(10.77)$ & $22(16.30)$ \\
Multipara & $2(3.08)$ & $5(3.70)$ \\
\hline
\end{tabular}

and $>35$ years was negligible (Table 2, Table 3 ).

Parity distribution pattern showed that occurrence of Nulliparity was much higher than Primiparity and Multiparity in both groups. Comparative analysis showed that for variables "Nullipara" and "Primipara" significant $(\mathrm{p}<0.05)$ difference was found between T and NT groups. Significantly more mothers in tribal group $(86.15 \%)$ were nulliparous than in nontribal group (80\%) whereas primiparous mothers were significantly more common in nontribal group (16.30\%) than tribal group (10.77\%). For variable "multipara" there was no significant ( $\mathrm{p}>$ 0.05 ) difference between two groups (Table 4, Figure 2 \& Figure 3). 


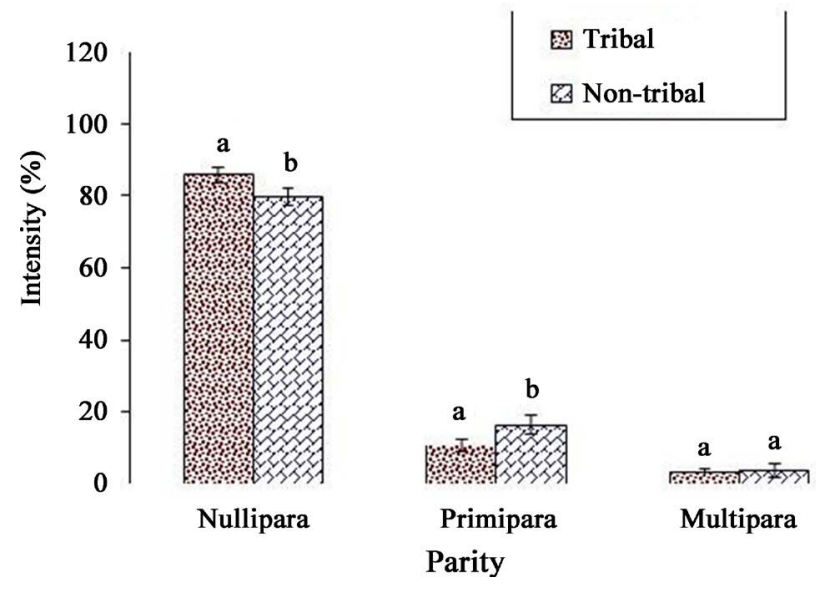

Figure 2. Comparative analysis showing the difference in parity in $\mathrm{T}$ and NT group with severe preeclampsia and eclampsia. (Each bar represents Mean \pm SEM in percentage value. Bars with different superscripts $(a, b)$ differ from each other significantly at the level of $p<0.05$. Bars having same superscript (a) does not differ from each other significantly $(\mathrm{p}>0.05)$.)

Table 4. State of consciousness of mothers in Tribal and Nontribal groups on the basis of Glasgow coma Scale (GCS).

\begin{tabular}{ccc}
\hline GCS on admission & T $(\mathbf{n}=\mathbf{6 5})$ No. (\%) & NT $(\mathbf{n}=135)$ No. (\%) \\
\hline$<8$ & $7(10.77)$ & $5(3.70)$ \\
$8-12$ & $10(15.38)$ & $23(17.04)$ \\
$13-15$ & $48(73.85)$ & $107(79.26)$ \\
\hline
\end{tabular}

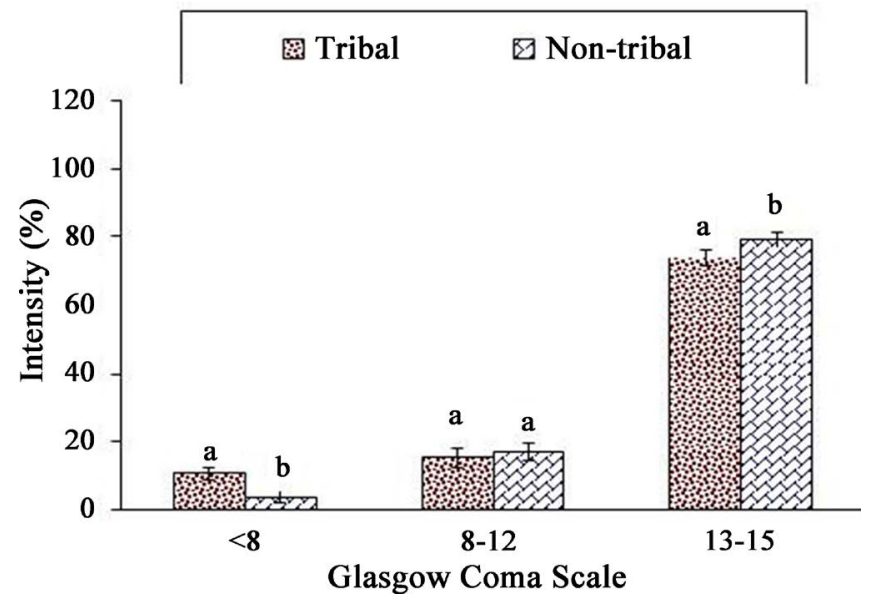

Figure 3. Comparison of the state of consciousness between $\mathrm{T}$ and NT groups on the basis of Glasgow Coma Scale. (Each bar represents Mean \pm SEM in percentage value. Bars with different superscripts $(a, b)$ differ from each other significantly at the level of $\mathrm{p}<$ 0.05. Bars having same superscript (a) does not differ from each other significantly ( $p>$ 0.05).)

For class " $<8$ " and " $13-15$ " tribal mothers showed significant $(\mathrm{p}<0.05)$ difference in intensity with nontribal mothers. For class " $8-12$ " no significant difference $(p>0.05)$ arrived. Unconsciousness (GCS $<8$ ) was more common in 
tribal group (10.77\%) than in nontribal group (3.70\%) and where as consciousness (GCS of 13 - 15) was more common in nontribal group (79.26\%) than tribal group $(73.85 \%)$.

Comparative analysis revealed that tribal mothers suffered from severe hypertension $(\geq 160 / 110 \mathrm{~mm}$ of $\mathrm{Hg})$ significantly $(\mathrm{p}<0.05)$ more commonly $(76.92 \%)$ than nontribal mothers $(69.60 \%)$ and significantly $(\mathrm{p}<0.05)$ more nontribal mothers $(30.40 \%)$ had blood pressure $<160 / 110 \mathrm{~mm}$ of $\mathrm{Hg}$ than tribal mothers (23.08\%).

There was significant $(\mathrm{p}<0.05)$ difference found for all grades of proteinuria between $\mathrm{T}$ and NT group. Proteinuria in general was more common in tribal than nontribal mothers. Proteinuria was absent or trace in significantly $(\mathrm{p}<$ $0.05)$ more number of nontribal mothers than tribal mothers whereas $1+$ and $2+$ proteinuria was significantly $(\mathrm{p}<0.05)$ more common in tribal than nontribal

Table 5. Comparison on the basis of blood pressure on admission between $\mathrm{T}$ and NT group.

\begin{tabular}{ccc}
\hline BP on admission (mmHg) & T ( $=$ =65) No. (\%) & NT (n = 135) No. (\%) \\
\hline$<160 / 110$ & $15(23.08)$ & $41(30.40)$ \\
$\geq 160 / 110$ & $50(76.92)$ & $94(69.60)$ \\
\hline
\end{tabular}

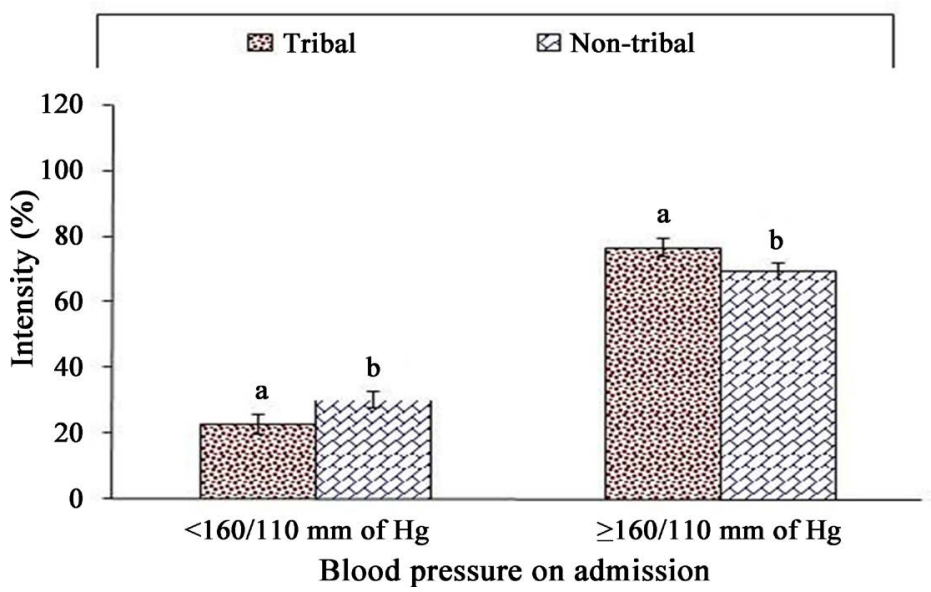

Figure 4. Showing the comparison of blood pressure on admission between $\mathrm{T}$ and NT group. (Each bar represents Mean \pm SEM in percentage value. Bars with different superscripts $(a, b)$ differ from each other significantly at the level of $\mathrm{p}<0.05$.)

Table 6. Urine for protein by dipstick method in Tribal and Nontribal group.

\begin{tabular}{ccc}
\hline Grades of proteinuria & $\mathrm{T}(\mathbf{n}=\mathbf{6 5})$ No. (\%) & NT $(\mathbf{n}=135)$ No. (\%) \\
\hline Negative & $17(26.15)$ & $49(36.3)$ \\
Trace & $16(24.6)$ & $38(28.15)$ \\
$1+$ & $22(33.85)$ & $28(20.74)$ \\
$2+$ & $7(10.77)$ & $10(7.4)$ \\
$\geq 3+$ & $3(4.6)$ & $10(7.4)$ \\
\hline
\end{tabular}




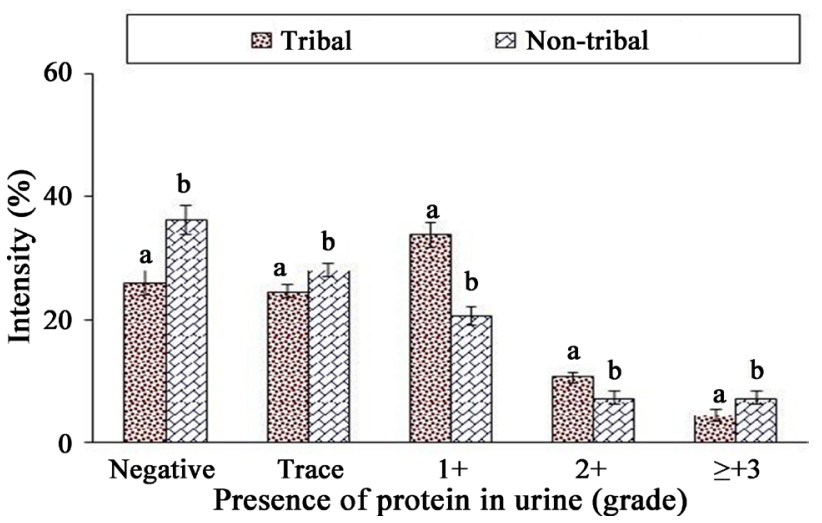

Figure 5. Comparison of proteinuria in tribal and nontribal mothers. (Each bar represents Mean \pm SEM in percentage value. Bars with different superscripts $(a, b)$ differ from each other significantly at the level of $\mathrm{p}<0.05$.)

Table 7. Comparison of severity of disease in Tribal and Nontribal group.

\begin{tabular}{ccc}
\hline Severity of disease & T $(\mathrm{n}=65)$ No. (\%) & NT $(\mathrm{n}=135)$ No. (\%) \\
\hline Convulsion $>4$ times & $23(35.4)$ & $79(58.5)$ \\
Severe hypertension $(\geq 160 / 110)$ & $50(76.9)$ & $94(69.6)$ \\
Proteinuria $(\geq 3+)$ & $3(4.6)$ & $10(7.4)$ \\
\hline
\end{tabular}

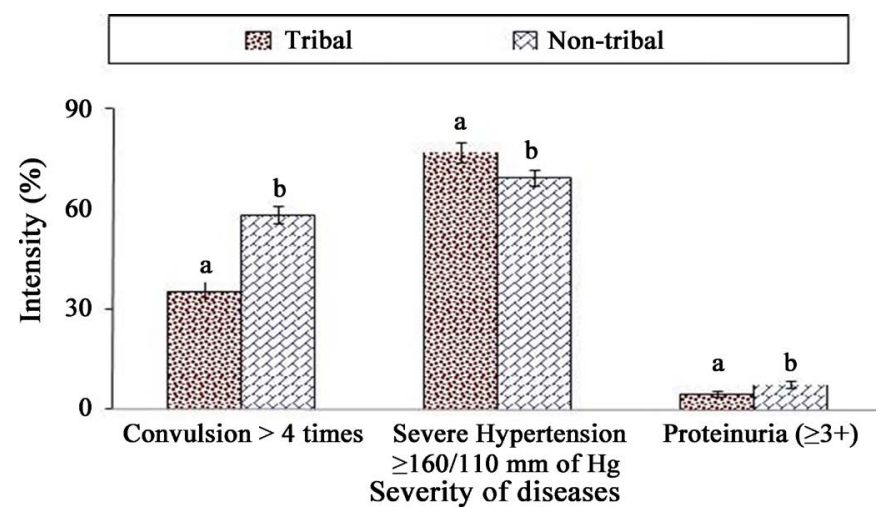

Figure 6. Comparative analysis of severity of disease in T and NT group. (Each bar represents Mean \pm SEM in percentage value. Bars with different superscripts $(a, b)$ differ from each other significantly $(\mathrm{p}<0.05)$. Bars having same superscript (a) does not differ from each other significantly $(\mathrm{p}>0.05)$.)

mothers. Severe proteinuria $(\geq 3+)$, though significantly $(\mathrm{p}<0.05)$ more common in nontribals, was in general infrequent in both groups (Tables 5-7 and Figures 4-6).

Comparative analysis revealed that tribal mothers suffered from severe hypertension $(\geq 160 / 110 \mathrm{~mm}$ of $\mathrm{Hg}$ ) significantly ( $\mathrm{p}<0.05)$ more commonly than NT group. Whereas nontribal mothers suffered significantly $(\mathrm{p}<0.05)$ more commonly from larger number of convulsions ( $>4$ times) when they developed eclampsia and severe proteinuria $(\geq 3+)$ than tribal mothers.

Pregnant mothers with blood pressure $>150 / 100 \mathrm{~mm}$ of $\mathrm{Hg}$ (51 in tribal group and 98 in nontribal group) needed antihypertensive drug (Inj. Labetalol) therapy (Tables 8-9 and Figures 7-8). 
Table 8. Response to treatment with antihypertensive drugs in respect of time taken for BP to come below 150/100 $\mathrm{mmHg}$ (in mothers having BP > 150/100 $\mathrm{mmHg}$ ).

\begin{tabular}{ccc}
\hline Time taken for BP control & T (51) No. (\%) & NT (98) No. (\%) \\
\hline$<1 / 2 \mathrm{hr}$ & $10(19.6)$ & $23(23.46)$ \\
$1 / 2 \mathrm{hr}-1 \mathrm{hr}$ & $19(37.25)$ & $43(43.9)$ \\
$>1 \mathrm{hr}$ & $22(43.14)$ & $32(32.65)$ \\
\hline
\end{tabular}

\begin{tabular}{|l|}
\hline Tribal Non-tribal \\
\hline
\end{tabular}

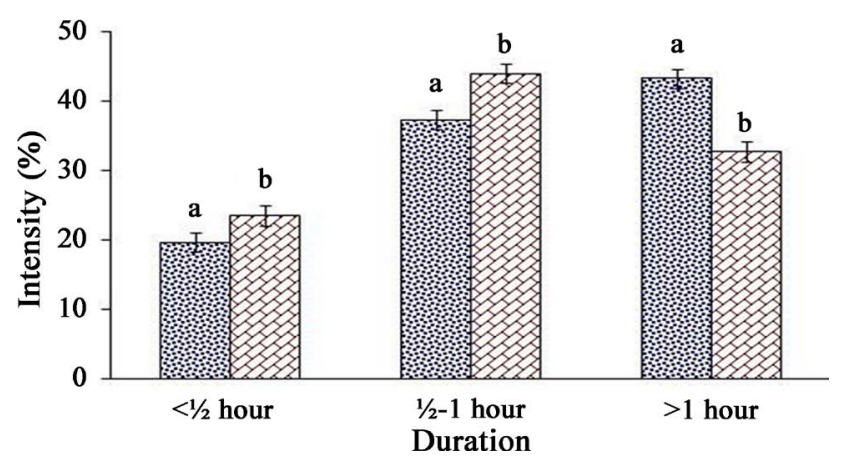

Figure 7. Comparison of response to antihypertensive drug treatment in mothers with BP > 150/100 mmHg in terms of time taken for BP to come below 150/100 mmHg. (Each bar represents Mean \pm SEM in percentage value. Bars with different superscripts $(a, b)$ differ from each other significantly at the level of $\mathrm{p}<0.01$.)

Table 9. Response to anticonvulsant treatment: Recurrence/occurrence of convulsion in Tribal and Nontribal mothers after loading dose of $\mathrm{MgSO}_{4}$.

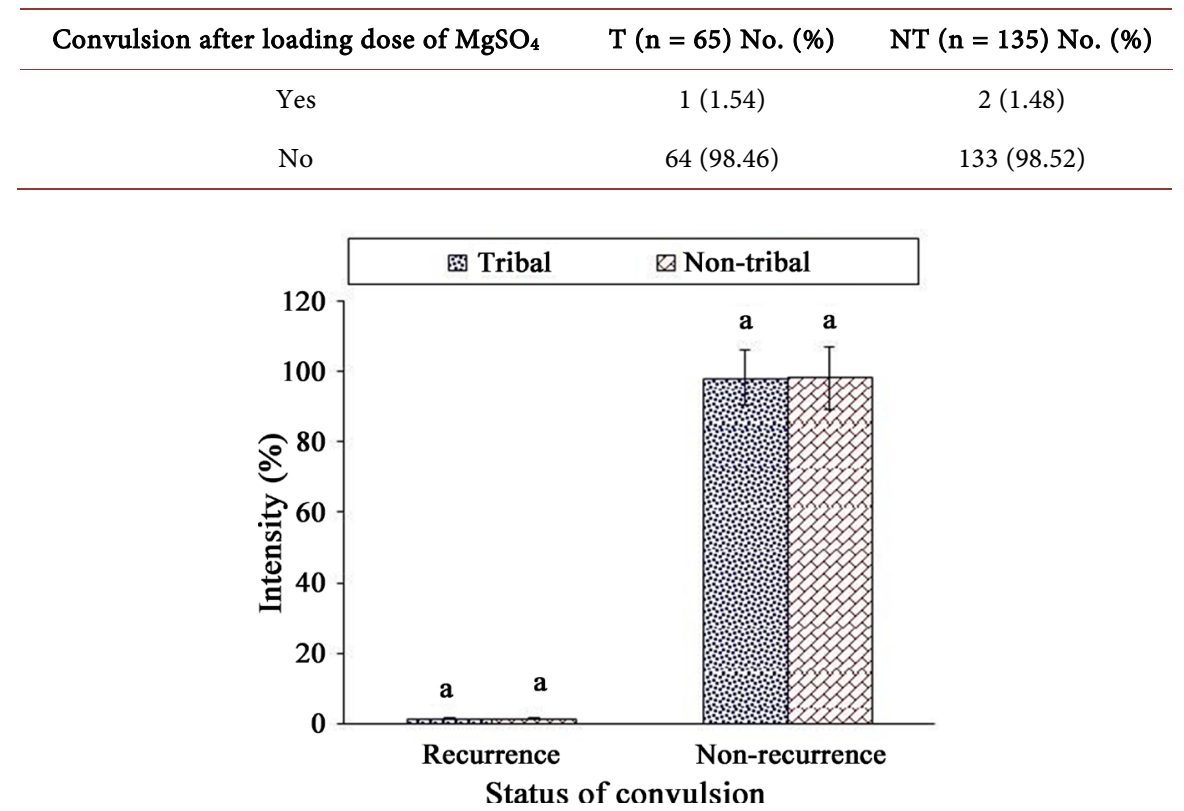

Figure 8. Comparison of response to anticonvulsant treatment with $\mathrm{MgSO}_{4}$ on the basis of recurrence/occurrence of convulsion after loading dose of $\mathrm{MgSO}_{4}$ in $\mathrm{T}$ and NT group. (Each bar represents Mean \pm SEM in percentage value. There is insignificant $(p>0.05)$ difference between the two groups.) 
Mothers in both groups responded well to such treatment though significantly $(<0.01)$ more nontribal mothers responded earlier and to a smaller dose of anti-hypertensive drug than tribal mothers, and thus needed a smaller dose of anti-hypertensive drug, than tribal mothers for control of BP to the desired level of $<150 / 100 \mathrm{mmHg}$ but not $<140 / 90 \mathrm{mmHg}$. Control of BP to the desired level required $\geq 1$ hour of anti-hypertensive therapy (and thus larger doses) in significantly $(<0.01)$ more number of tribal mothers $(43.14 \%)$ than nontribal mothers (32.65\%).

Vast majority of mothers (98.46\% of tribal mothers and $98.52 \%$ of nontribal mothers) in both the groups responded very well to anticonvulsant therapy with $\mathrm{MgSO}_{4}$ and $\mathrm{MgSO}_{4}$ was very effective in controlling convulsion in eclampsia and preventing it in case of severe preeclampsia in most mothers in both groups. Only a tiny fraction of mothers in both groups had convulsion after treatment was started with the loading dose of $\mathrm{MgSO}_{4}$ and there was no significant difference $(p>0.05)$ between the two groups.

Majority of mothers of both groups were already in labour at the time of admission. But comparative analysis revealed that the tribal mothers presented in labour significantly $(\mathrm{p}<0.05)$ more commonly than nontribal mothers, in both first stage $(56.92 \%$ vs. $51.85 \%)$ and second stage $(10.77 \%$ vs. $7.41 \%)$ of labour while antepartum (not in labour) mothers were significantly $(\mathrm{p}<0.05)$ more

Table 10. Labour status on admission in Tribal and Nontribal groups.

\begin{tabular}{ccc}
\hline Status of labour & T (n= 65) No. (\%) & NT (n = 135) No. (\%) \\
\hline Stage I & $37(56.92)$ & $70(51.85)$ \\
Stage II & $7(10.77)$ & $10(7.41)$ \\
Not in labour & $18(27.69)$ & $49(36.30)$ \\
Delivered & $3(4.62)$ & $6(4.44)$ \\
\hline
\end{tabular}

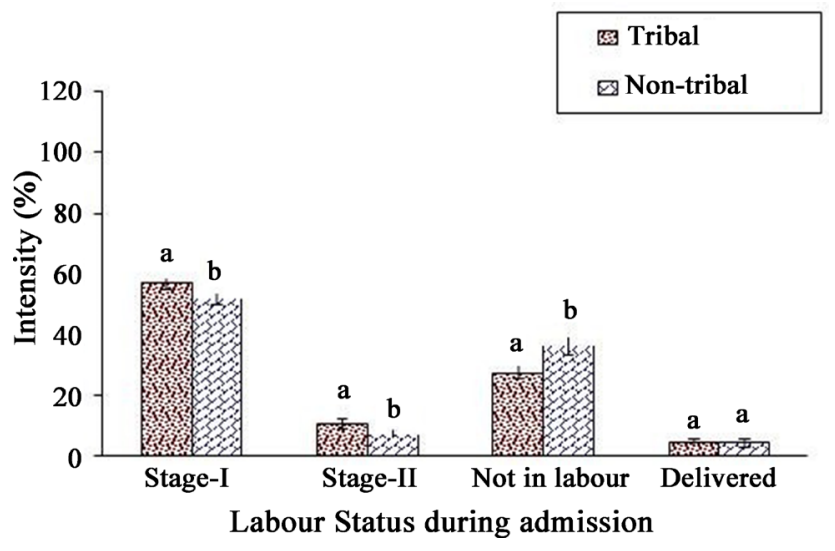

Figure 9. Comparison of Labour status on admission in $\mathrm{T}$ and NT group. (Each bar represents Mean \pm SEM in percentage value. Comparative analysis performed by student two-tail t-test for means. Bars with different superscripts $(a, b)$ differ from each other significantly $(\mathrm{p}<0.05)$. Bars with same superscript $(a)$ does not differ from each other significantly $(p>0.05)$.) 
common in nontribal group than tribal group (36.30\% Vs $27.69 \%)$. Few mothers were admitted after delivery and the recorded intensities showed insignificant ( $p>0.05$ ) difference between the selected two groups (Table 10 and Figure 9).

Comparative analysis of different modes of delivery in tribal $(n=62)$ and nontribal $(\mathrm{n}=129)$ mothers (admitted in ante partum and intra partum period) revealed that vaginal delivery (VD), both Normal VD and Assisted VD were significantly $(\mathrm{p}<0.05)$ more common in tribal group than nontribal group where as LSCS (Lower uterine Segment Caesarean Section) was significantly $(\mathrm{p}<0.05)$ more common in nontribal group than the tribal group.

Relatively few mothers presented in postpartum period and comparative analysis of modes of delivery in those mothers showed that LSCS was significantly more common $(\mathrm{p}<0.01)$ in nontribal mothers $(66.66 \%)$ than tribal mothers (33.33\%).

Majority of the mothers in both groups survived. Comparative analysis revealed that maternal mortality was significantly more common $(p<0.05)$ in the

Table 11. Comparison of mode of delivery in Antepartum and Intrapartum tribal and nontribal mothers.

\begin{tabular}{ccc}
\hline \multirow{2}{*}{ Mode of Delivery } & Tribal $(\mathrm{n}=62)$ & Nontribal $(\mathrm{n}=129)$ \\
\cline { 2 - 3 } & \multicolumn{2}{c}{$\%$} \\
\hline Normal VD & $30.65 \pm 1.81^{\mathrm{a}}$ & $20.93 \pm 2.10^{\mathrm{b}}$ \\
Assisted VD & $6.45 \pm 1.06^{\mathrm{a}}$ & $3.10 \pm 1.02^{\mathrm{b}}$ \\
LSCS & $62.90 \pm 1.98^{\mathrm{a}}$ & $75.97 \pm 2.48^{\mathrm{b}}$ \\
Undelivered & 0 & 0 \\
\hline
\end{tabular}

(Data were expressed as Mean \pm SEM in percentage value. Comparative analysis performed by Student two tail " $t$ " test for means. Values of each row with different superscripts (a, b) differ from each other significantly $(\mathrm{p}<0.05)$.)

Table 12. Mode of delivery in tribal and nontribal mothers admitted after delivery.

\begin{tabular}{ccc}
\hline & Tribal $(\mathrm{n}=3)$ & Nontribal $(\mathrm{n}=6)$ \\
\cline { 2 - 3 } Mode of Delivery & \multicolumn{2}{c}{$\%$} \\
\hline Normal VD & $33.33 \pm 2.19^{\mathrm{a}}$ & $33.33 \pm 2.31^{\mathrm{a}}$ \\
Assisted VD & $0 \pm 0.00^{\mathrm{a}}$ & $33.33 \pm 2.30^{\mathrm{b}}$ \\
LSCS & $66.66 \pm 2.44^{\mathrm{a}}$ & $33.33 \pm 2.31^{\mathrm{b}}$ \\
Undelivered & 0 & 0 \\
\hline
\end{tabular}

(Data were expressed as Mean \pm SEM in percentage value. Comparative analysis performed by Student two tail t-test for means. Values of each row with different superscripts (a,b) differ from each other significantly $(\mathrm{p}<0.01))$.

Table 13. Maternal outcome in Tribal and Nontribal groups.

\begin{tabular}{ccc}
\hline Maternal Outcome & $\mathrm{T}(\mathrm{n}=\mathbf{6 5})$ No. (\%) & NT $(\mathrm{n}=\mathbf{1 3 5})$ No. (\%) \\
\hline Mortality & $7(10.77)$ & $8(5.92)$ \\
Survived & $58(89.23)$ & $127(94.07)$ \\
\hline
\end{tabular}




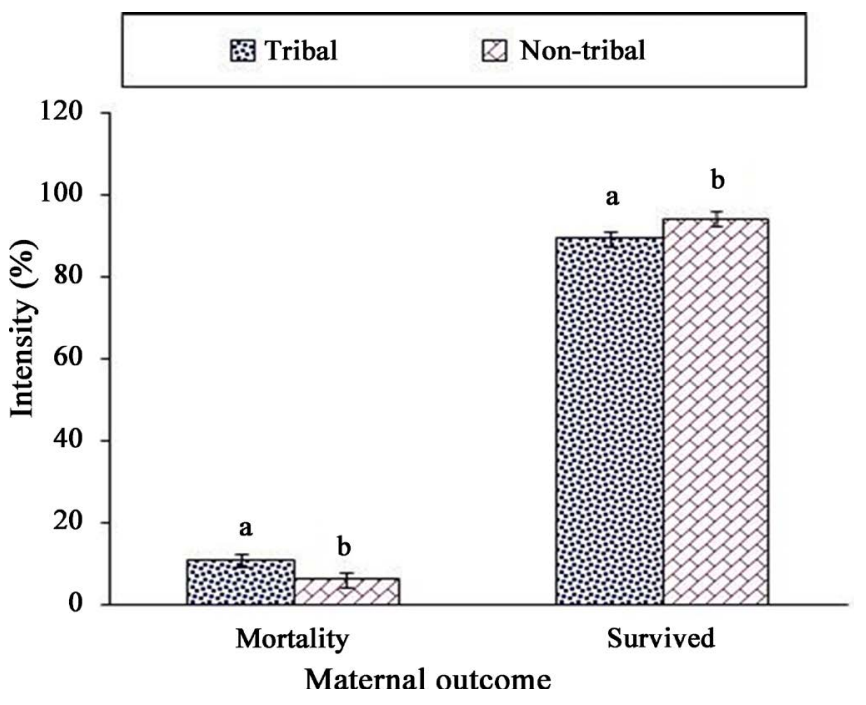

Figure 10. Comparison of maternal outcome in T and NT group. (Each bar represents Mean \pm SEM in percentage value. Bars having different superscripts $(a, b)$ differ from each other significantly $(\mathrm{p}<0.05)$.)

Table 14. Different complications suffered by tribal and nontribal mothers.

\begin{tabular}{ccc}
\hline \multirow{2}{*}{ Maternal complication } & Tribal & Nontribal \\
\cline { 2 - 3 } & \multicolumn{2}{c}{$\%$} \\
\hline Pulmonary embolism & $1.54 \pm 0.19^{\mathrm{a}}$ & $2.96 \pm 0.24^{\mathrm{b}}$ \\
Pulmonary Edema & $1.54 \pm 0.18^{\mathrm{a}}$ & $1.48 \pm 0.33^{\mathrm{a}}$ \\
CVA & $6.15 \pm 0.59^{\mathrm{a}}$ & $0.74 \pm 0.16^{\mathrm{b}}$ \\
RF & $1.54 \pm 0.17^{\mathrm{a}}$ & $0.74 \pm 0.14^{\mathrm{b}}$ \\
Cerebral edema & $1.54 \pm 0.18^{\mathrm{a}}$ & $0.74 \pm 0.13^{\mathrm{b}}$ \\
Hypovolemic shock & $0 \pm 0.00^{\mathrm{a}}$ & $0.74 \pm 0.13^{\mathrm{b}}$ \\
HELLP syndrome & $1.54 \pm 0.19^{\mathrm{a}}$ & $0 \pm 0.00^{\mathrm{b}}$ \\
\hline
\end{tabular}

(Each row represents Mean \pm SEM in percentage value. Values with same superscript (a) does not differ from each other significantly $(p>0.05)$. Values of each row with different superscripts $(a, b)$ differ from each other significantly $(\mathrm{p}<0.05))$.

tribal group (10.77\%) than the nontribal group (5.92\%) (Tables 11-14 and Figure 10).

Frequencies of pregnant mothers of both $\mathrm{T}$ and NT group suffered from different complications were compared statistically. Overall rate of serious complications was low. Final outcome showed that there was significant $(\mathrm{p}<0.05)$ difference in between these two groups for all the parameters except for 'Pulmonary edema' parameters $(\mathrm{p}>0.05)$. Tribal mothers suffered more commonly from cerebrovascular accidents (CVA) than nontribals who suffered more commonly from pulmonary embolism.

Comparative analysis revealed significant $(\mathrm{p}<0.01)$ difference between these groups. Tribal mothers needed admission to ICU significantly $(\mathrm{p}<0.01)$ more commonly (12.31\%) than nontribal mothers $(5.92 \%)$. 
Table 15. Need of ICU admission by tribal and nontribal mothers.

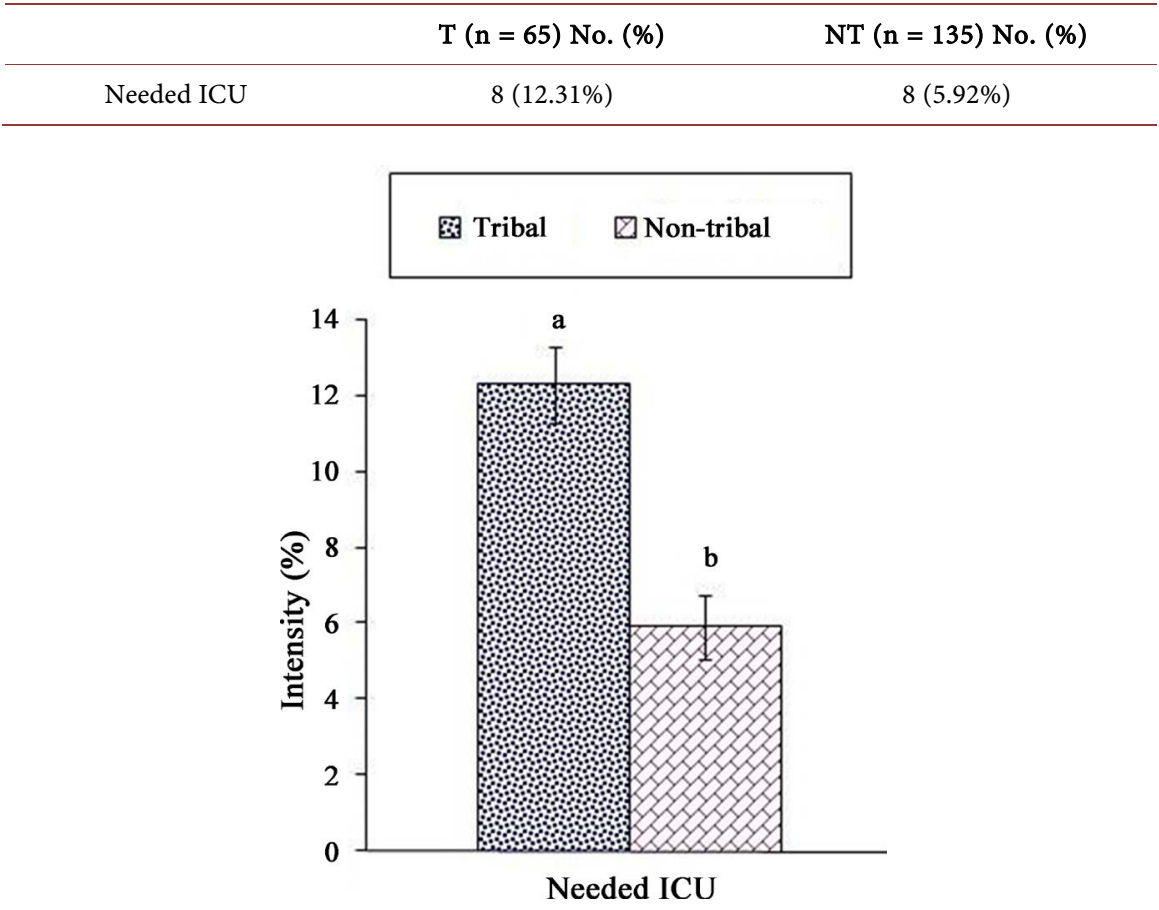

Figure 11. Comparison on the basis of need of ICU by tribal and nontribal mothers. (Each bar represents Mean \pm SEM in percentage value. Values with different superscripts $(\mathrm{a}, \mathrm{b})$ differ from each other significantly at the level of $\mathrm{p}<0.01$.)

Table 16. Hospital stay by survived mothers in Tribal and Nontribal group.

\begin{tabular}{ccc}
\hline Duration of hospital stay & $\mathrm{T}(\mathrm{n}=\mathbf{5 8})$ No. (\%) & NT $(\mathrm{n}=\mathbf{1 2 7})$ No. (\%) \\
\hline $\mathbf{7}$ days & $53(91.38)$ & $118(92.9)$ \\
$>7$ days & $5(8.62)$ & $9(7.09)$ \\
\hline
\end{tabular}

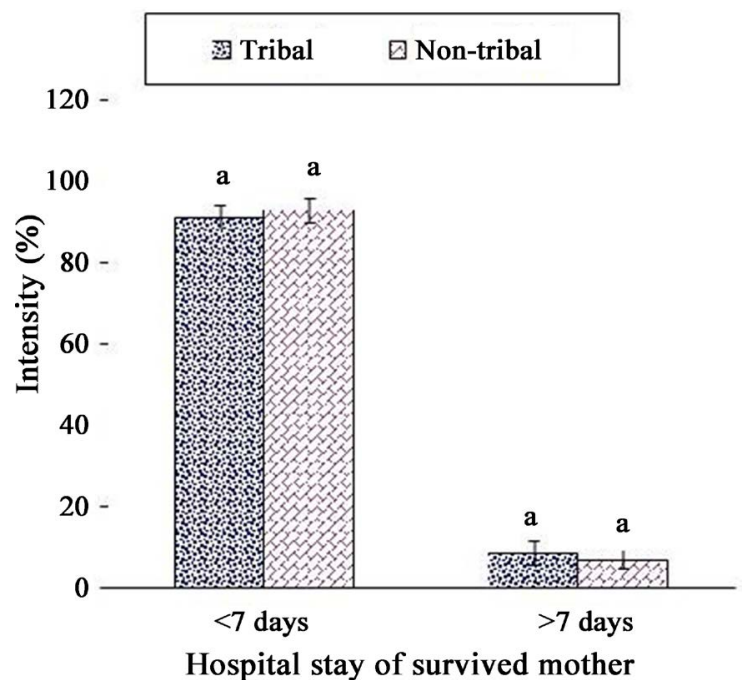

Figure 12. Comparison on the basis of duration of hospital stay by survived mothers in $\mathrm{T}$ and NT group. (Each bar represents Mean \pm SEM in percentage value. Bars having same superscript (a) does not differ from each other significantly $(p>0.05)$.) 
Table 17. Foetal outcome in Tribal and Nontribal groups.

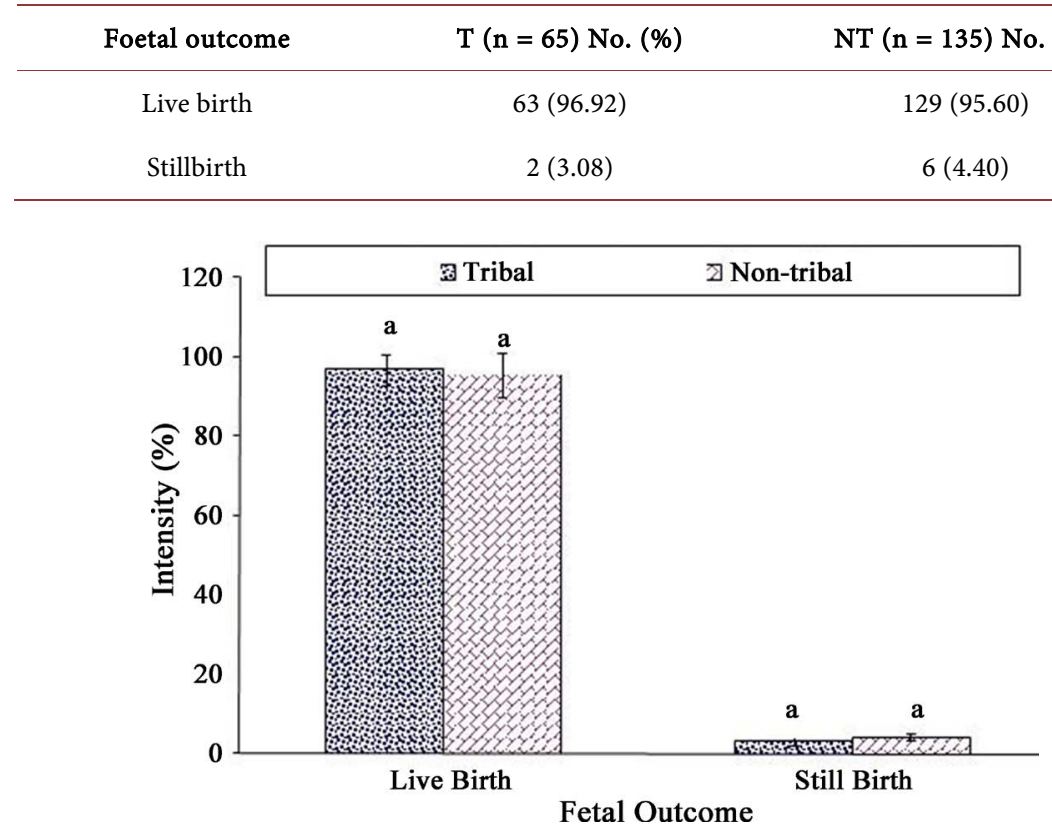

Figure 13. Comparison on the basis of foetal outcome in T and NT group. (Each bar represents Mean \pm SEM in percentage value. Bars having same superscript (a) does not differ from each other significantly $(\mathrm{p}>0.05)$.)

Table 18. Birth asphyxia in newborn babies delivered in $\mathrm{MMCH}$ in Tribal and Nontribal groups.

\begin{tabular}{lcc}
\hline & $\mathrm{T}(\mathrm{n}=63)$ No. (\%) & NT $(\mathrm{n}=129)$ No. (\%) \\
\hline Asphyxiated new born baby & $5(7.90)$ & $17(13.18)$ \\
\hline
\end{tabular}

Hospital stay for $\leq 7$ days by survived tribal and nontribal mothers represented a higher frequency and their comparative analysis showed insignificant $(p>0.05)$ difference in between them. Alongside comparative analysis in between frequencies of mothers with hospital stay for $>7$ days duration also revealed insignificant ( $\mathrm{p}>$ 0.05) difference in between these two groups (Tables 15-18 and Figures 11-13).

Tribal and nontribal both the groups exhibited higher frequency of live births (96.92\% and $95.60 \%$ respectively) in comparison to still birth babies with insignificant ( $p>0.05$ ) difference in between these two study groups.

Comparative analysis showed a significant $(\mathrm{p}<0.001)$ higher percentage of asphyxiated foetal outcomes in nontribal study group (13.18\%) than in tribal group (7.90\%).

Neonatal death was rare. Need for admission to NICU was almost similar (insignificant, $\mathrm{p}>0.05)$ in the two groups, but there was a significant $(\mathrm{p}<0.05)$ higher percentage of preterm babies in nontribal group (17.04\%) than tribal group (12.31\%).

Significantly $(\mathrm{p}<0.001)$ greater percentage of new borns of tribal group $(60 \%)$ were low birth weight $(<2.5 \mathrm{Kg})$ in comparison to new borns of the nontribal group (45.93\%) (Tables 19-20 and Figures 14-15). 


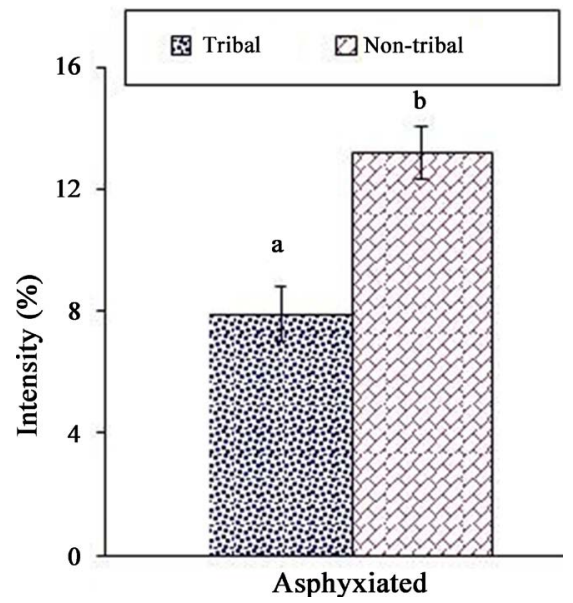

Figure 14. Comparison on the basis of birth of asphyxiated newborn baby in T and NT group. (Values differ from each other significantly at the level of $\mathrm{p}<0.001$.)

Table 19. Foetal outcome: neonatal death, NICU admission and preterm birth in Tribal and Nontribal group.

\begin{tabular}{ccc}
\hline Complications of foetus & T $(\mathrm{n}=65)$ & NT $(\mathrm{n}=135)$ \\
\hline Neonatal Death & $1.54 \pm 0.68^{\mathrm{a}}$ & $0 \pm 0.00^{\mathrm{b}}$ \\
Needed NICU & $23.08 \pm 1.48^{\mathrm{a}}$ & $22.96 \pm 1.89^{\mathrm{a}}$ \\
Preterm & $12.31 \pm 1.86^{\mathrm{a}}$ & $17.04 \pm 1.79^{\mathrm{b}}$ \\
\hline
\end{tabular}

(Data were expressed as Mean \pm SEM in percentage value. Values of each row with different superscripts (a, b) differ from each other significantly $(\mathrm{p}<0.05)$. Values having same superscript (a) does not differ from each other significantly $(p>0.05)$.)

Table 20. Birth weight in Tribal and Nontribal groups.

\begin{tabular}{ccc}
\hline Birth weight (kgs) & T ( $\mathrm{n}=65)$ No. (\%) & NT ( $=135)$ No. (\%) \\
\hline$<2.5$ & $39(60)$ & $62(45.93)$ \\
$\geq 2.5$ & $26(40)$ & $73(54.07)$ \\
\hline
\end{tabular}

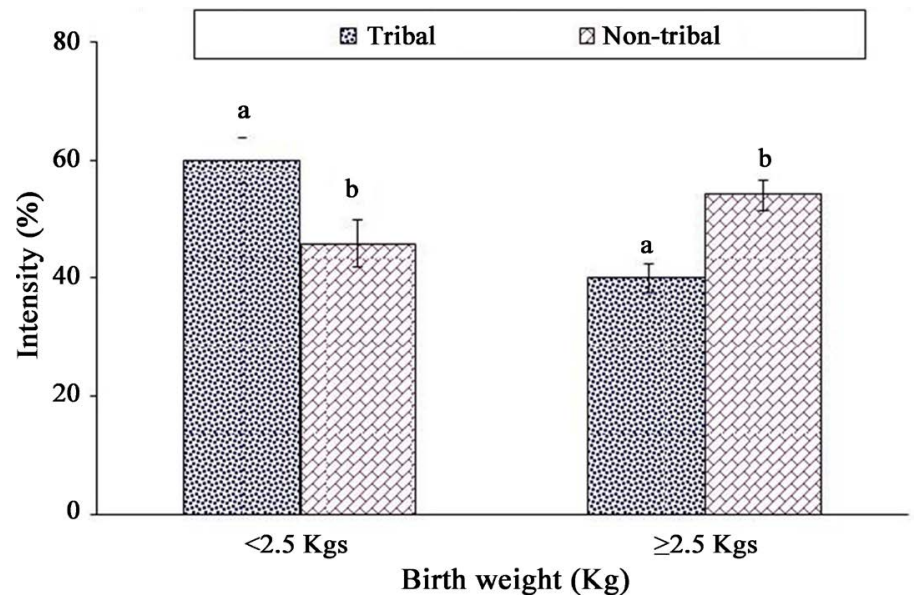

Figure 15. Comparison of birth weight in T and NT group. (Each bar represents Mean \pm SEM in percentage value. Bars with different superscripts $(a, b)$ differ from each other significantly at the level of $\mathrm{p}<0.001$.) 


\section{Discussion}

In the presented study, there were 65 mothers in Tribal (T) group and 135 mothers in Nontribal (NT) group. Of them 133 mothers had severe preeclampsia and 67 mothers had eclampsia. Total number of deliveries conducted in this hospital was 3768 during the study period. Out of this tribal women were 576 and nontribal women were 3192 . Thus, during the study period the overall incidence of severe preeclampsia and eclampsia in our institution were $3.53 \%$ and $1.78 \%$ respectively. The incidence of severe preeclampsia and eclampsia in tribal women were $7.29 \%$ and $3.99 \%$ respectively, and in nontribal women were $2.85 \%$ and $1.38 \%$ respectively. The incidence was found to be significantly $(\mathrm{p}<0.001)$ higher in T group than NT group. Other studies which have examined the association of maternal ethnicity and severe preeclampsia and eclampsia also found some ethnic groups at higher risk than other ethnic or racial groups. Myles Wolf et al. found Hispanic ethnicity to be independently associated with increased risk for preeclampsia and decreased risk for gestational hypertension [55] [56] [57] [58] [59]. Bryant AS et al. found Black women with hypertension in pregnancy in the absence of chronic hypertension more likely to be diagnosed with preeclampsia than were White women [50].

Advanced maternal age has been found to be an independent risk factor for preeclampsia, while in this study most of the mothers of both T and NT group were under 25 years of age, which is probably because we were dealing with women from rural area, where early marriage is more common. The incidence of severe preeclampsia and eclampsia was significantly $(\mathrm{p}<0.05)$ higher in tribal women of 20 yrs and below than NT group, whereas in 21 to 25 yrs of age group nontribal women were found to be more affected than tribal women. Myles Wolf et al. found that Hispanic women were younger than non-Hispanic and Caucasian groups [59] [60] [61] [62]. Goodwin AA et al. reported that Caucasian women were older (27 vs. 24 yrs) than African American women [51].

In our study, severe preeclampsia and eclampsia were more common in nulliparous and primiparous women of both groups but the incidence was significantly $(\mathrm{p}<0.05)$ higher in nulliparous tribal women $(86.15 \%)$ than nontribals $(80 \%)$, whereas primiparous mothers were significantly more common in nontribal group (16.30\%) than tribal group (10.77\%). Goodwin AA et al. found Caucasian women more likely nulliparous than African American and Hispanic women [51]. Depending on ethnicity, the incidence of preeclampsia ranges from $3 \%$ to $7 \%$ in healthy nulliparas [36]. Gaurav Ghosh et al. reported that nulliparous Hispanic women and Asian/Pacific Islanders had an overall decreased risk compared to non-Hispanic whites [52]. A. K. Rao et al. found that among primiparous women, there is a disparity among ethnic groups as the risk in African American women is twice that of Caucasian women, and the risk is also very high in women of Indian and Pakistani origin [63]-[73].

In the presented study, $\mathrm{T}$ group demonstrated more severe hypertension than NT group. Goodwin AA et al. found that African Americans had more severe 
hypertension where as Hispanic women had less severe hypertension [51].

In our study, Mothers in both groups responded well to treatment but control of blood pressure to the desired level required $\geq 1$ hour of anti-hypertensive therapy (and thus larger doses) in significantly $(<0.01)$ more number of tribal mothers $(43.14 \%)$ than nontribal mothers (32.65\%). Tribal mothers were found to be less responsive to treatment than nontribal mothers, whereas nontribal mothers responded earlier and to a smaller dose of anti-hypertensive drug than tribal mothers, and thus needed a smaller dose of anti-hypertensive drug than tribal mothers. This finding is in agreement with what Goodwin AA et al. found among African American women as they needed more antihypertensive treatment intrapartum, postpartum and at discharge $(\mathrm{p}<0.03)$ than Hispanic women [51].

No significant $(\mathrm{p}>0.05)$ difference in recurrence of convulsion after anticonvulsant treatment was found between the two groups. Goodwin AA et al. found no difference in severe proteinuria among Caucasian, African American and Hispanic women [51] whereas in our study, proteinuria was significantly more common in $\mathrm{T}$ group, but severe proteinuria $(\geq 3+)$, though uncommon in both groups, was more common in nontribals.

T group presented with poorer GCS score on admission than NT group. Nontribal women experienced more number of convulsions than $\mathrm{T}$ group.

Regarding the obstetrical condition on admission, most of the tribal and nontribal women had gone into labour, but it was found significantly more commonly in $\mathrm{T}$ group, while antepartum (not in labour) mothers were significantly $(\mathrm{p}<0.05)$ more common in nontribal group than tribal group $(36.30 \% \mathrm{Vs}$ $27.69 \%)$. In our study, tribal women found in stage I of labour were $56.9 \%$ and in stage II were $10.77 \%$, which was significantly $(\mathrm{p}<0.05$ ) higher than $51.85 \%$ and $7.4 \%$ respectively of nontribal women.

In our study, $30.65 \%$ of tribal women were delivered vaginally and $6.45 \%$ were delivered by assisted vaginal delivery (forceps delivery), which were significantly higher than nontribal women, $20.93 \%$ and $3.10 \%$ respectively. $75.97 \%$ of nontribal women were delivered by lower segment caesarean section (LSCS) than $62.9 \%$ tribal women. Myles Wolf et al. found that Hispanic women were less likely to deliver by Caesarean section than non-Hispanic Caucasian groups.

There were no cases of undelivered in our study. There was no significant difference found between $\mathrm{T}$ and $\mathrm{NT}$ group regarding modes of delivery in postpartum mothers.

In our study, regarding the maternal outcome, maternal mortality was significantly more common $(\mathrm{p}<0.05)$ in the tribal group $(10.77 \%)$ than the nontribal group (5.92\%). Maternal mortality was reported to be high among various tribal groups due to hypertensive disorders of pregnancy [74]. Black women with preeclampsia-eclampsia are more likely to die from these conditions than White women [75] [76] [77] [78].

The $\mathrm{T}$ group, in our study, found to be at higher risk of getting complicated 
with cerebrovascular accidents when they develop severe preeclampsia or eclampsia than NT group, whereas pulmonary embolism was found to be more common in nontribal women. Aparna Khan et al. found cerebral haemorrhage (40\%) as the most common cause of death in their study. In Africa, $45.5 \%$ of hypertensive maternal death was due to cerebral complications. Goodwin AA et al. found that Caucasian women have more frequent HELLP syndrome [51]. Tribal mothers needed admission to ICU significantly ( $\mathrm{p}<0.01)$ more commonly (12.31\%) than nontribal mothers (5.92\%). There was no significant difference found between $\mathrm{T}$ and NT group for duration of hospital stay.

Regarding the foetal outcome in T and NT group, in our study, the incidence of live births and stillbirths were similar in both groups. The new born babies of nontribal mothers suffered significantly more commonly from birth asphyxia than new borns of $\mathrm{T}$ group (17\% vs $5 \%$ ). In two studies by Goodwin AA et al. [51] and Myles Wolf et al. [59], no difference in foetal death rates was found among different ethnic groups. There was one neonatal death recorded in $\mathrm{T}$ group in our study. The incidence of preterm births was found to be more in NT group than $\mathrm{T}$ group.

Our study is consistent with the other studies in respect of LBW babies. In our study, we found the incidence of LBW babies significantly $(\mathrm{p}<0.001)$ higher in T group (60\%) than NT group (45.9\%). Fang J et al. found that the population attributable risk of LBW in hypertensive mothers was highest among blacks and lowest among whites. They concluded that maternal hypertension is an important risk factor for LBW in New York City. Its impact, however, differed by race/ethnicity groups [72]. Odell CD et al. reported that differences in maternal risk factors and rates of LBW exist between Haitian and African-American women delivering infants in Massachusetts. While chronic hypertension and preeclampsia are strong risk factors for LBW for both Haitian and African-American women, "unknown factors" make these disorders much more potent for Haitian women [27]. Those unknown factors may be related to their race or ethnicity and this observation corroborates with our finding of higher incidence of LBW in ethnic tribals than nontribals.

In our study the admission to NICU was required in a small number of babies and the need for admission to NICU was found to be almost similar in both groups. This may be due to higher rate of delivery of asphyxiated infant and preterm babies in NT group which compensated the higher rate of SGA babies in T group.

\section{Conclusions}

Hypertensive disorders of pregnancy remain an important maternal health problem in India. By this comparative study, we came to a conclusion that the tribal women are at higher risk of developing severe preeclampsia and eclampsia than nontribal women.

It is well established that extremes of age and nulliparity are strong risk factors 
for preeclampsia-eclampsia but these factors make the tribal ethnicity more prone to the disease.

Tribal women develop more severe hypertension and are less responsive to antihypertensive treatment than nontribal women.

Rate of caesarean section is high in both tribal and non tribal women with severe preeclampsia-eclampsia but comparatively higher among nontribal women.

The mortality and need of ICU care are more in tribal mothers than nontribal mothers when they develop severe preeclampsia-eclampsia.

Low birth weight neonates are more common in tribal women than nontribals whereas birth asphyxia and preterm births are more common in nontribal women.

These significant differences among the two groups suggest a strong role for ethnicity in the risk and pathogenesis of preeclampsia-eclampsia and it warrants further studies to understand it more clearly.

More awareness among both the tribal and non tribal group and routine antenatal checkup might improve the feto-maternal outcome in these groups of individuals (Q.7).

\section{Conflicts of Interest}

The authors declare no conflicts of interest regarding the publication of this paper.

\section{References}

[1] Vanderjagt, D.J., Patel, R.J., El Nafaty, A.U., Melah, G.S., Crossey, M.J. and Glew, R.H. (2004) High-Density Lipoprotein and Homocysteine Levels Correlate Inversely in Preeclamptic Women in Northern Nigeria. Acta Obstetricia et Gynecologica Scandinavica, 83, 536-542. https://doi.org/10.1111/j.1600-0412.2004.00513.x

[2] Eiland, E., Nzerue, C. and Faulkner, M. (2012) Preeclampsia 2012. Journal of Pregnancy, 2012, Article ID: 586578. https://doi.org/10.1155/2012/586578

[3] Roberts, J.M., August, P.A., Bakris, G., et al. (2013) Hypertension in Pregnancy. Report of the American College of Obstetricians and Gynecologists' Task Force on Hypertension in Pregnancy. Obstetrics \& Gynecology, 122, 1122-1131.

[4] Al Jameil, A.K. and Fareed Khan, T. (2014) A Brief Overview of Preeclampsia. Journal of Clinical Medicine Research, 6, 1-7.

[5] Zenebe, W., Hailemariam, S. and Mirkuzie, W. (2011) Hypertensive Disorders of Pregnancy in Jimma University Specialized Hospital. Ethiopian Journal of Health Sciences, 21, 147-154. https://doi.org/10.4314/ejhs.v21i1.69038

[6] Wallis, A.B., Saftlas, A.F., Hisa, J. and Atrash, H.K. (2008) Secular Trends in the Rates of Preeclampsia, Eclampsia, and Gestational Hypertension, United States, 1987-2004. American Journal of Hypertension, 21, 521-526. https://doi.org/10.1038/ajh.2008.20

[7] Duley, L. (2009) The Global Impact of Pre-Eclampsia and Eclampsia. Seminars in Perinatology, 33, 130-137. https://doi.org/10.1053/j.semperi.2009.02.010

[8] World Health Organization (WHO) (2005) Make Every Mother and Child Count. World Health Report. Geneva. 
[9] Dolea, C. and AbouZahr, C. (2003) Global Burden of Hypertensive Disorders of Pregnancy in the Year 2000. Global Burden of Diseases 2000 Working Paper. World Health Organization (WHO), Geneva.

[10] Gupte, S. and Wagh, G. (2014) Preeclampasia-Eclampsia. The Journal of Obstetrics and Gynecology of India, 64, 4-13. https://doi.org/10.1007/s13224-014-0502-y

[11] Khan, K.S., Wojdyla, D., Say, L., Gulmezoglu, A.M. and Van Look, P.F. (2006) WHO Analysis of Causes of Maternal Death: A Systematic Review. The Lancet, 367, 1066-1074. https://doi.org/10.1016/S0140-6736(06)68397-9

[12] (2007) Balancing the Scales: Expanding Treatment for Pregnant Women with Life-Threatening Hypertensive Conditions in Developing Countries. A Report on Barriers and Solutions to Treat Preeclampsia and Eclampsia. Engender Health.

[13] Altman, D., Carroli, G., Duley, L., Farrell, B., Moodley, J., Neilson, J., Smith, D. and Magpie Trial Collaboration Group (2002) Do Women with Preeclampsia, and Their Babies, Benefit from Magnesium Sulphate? The Magpie Trial: A Randomised Placebo-Controlled Trial. The Lancet, 359, 1877-1890. https://doi.org/10.1016/S0140-6736(02)08778-0

[14] Walker, J.J. (2000) Pre-Eclampsia. The Lancet, 356, 1260-1265. https://doi.org/10.1016/S0140-6736(00)02800-2

[15] Schutte, J.M., Steegers, E.A., Schuitemaker, N.W., et al. (2010) Rise in Maternal Mortality in the Netherlands. Netherlands Maternal Mortality Committee. BJOG, 117, 399-406. https://doi.org/10.1111/j.1471-0528.2009.02382.x

[16] Lopez Jaramillo, P., Casas, J.P. and Serrano, N. (2001) Preeclampsia: From Epidemiological Observation to Molecular Mechanisms. Brazilian Journal of Medical and Biological Research, 34, 1227-1235. https://doi.org/10.1590/S0100-879X2001001000001

[17] Okereke, E., Ahonsi, B., Tukur, J., Ishaku, S.M. and Oginni, A.B. (2012) Benefits of Using Magnesium Sulphate $\left(\mathrm{MgSO}_{4}\right)$ for Eclampsia Management and Maternal Mortality Reduction: Lessons from Kano State in Northern Nigeria. Population Council. BMC Research Notes, 5, 421. https://doi.org/10.1186/1756-0500-5-421

[18] Abubakar, A., Abdullahi, R.A., Jibril, H.Z., Dauda, M.H. and Poopola, M.A. (2009) Maternal Ethnicity and Severity of Pre-Eclampsia in Northern Nigeria. Asian Journal of Medical Sciences, 1, 104-107.

[19] Aaserud, M., Lewin, S. and Innvaer, S. (2005) Translating Research into Policy and Practice in Developing Countries: A Case Study of Magnesium Sulphate for Pre-Eclampsia. BMC Health Services Research, 5, 68.

https://doi.org/10.1186/1472-6963-5-68

[20] WHO, UNICEF, UNFPA, The World Bank, and United Nations Population Division Maternal Mortality Estimation Inter-Agency Group (2013) Maternal Mortality in 1990-2013.

[21] Registrar General, India, Centre for Global Health Research, University of Toronto, Canada (2006) Maternal Mortality in India 1997-2003 Trends, Causes and Risk Factors. New Delhi Registrar General, New Delhi.

[22] Sachan, R., Patel, M.L., Sachan, P., Gaurav, A., Singh, M. and Bansal, B. (2013) Outcomes in Hypertensive Disorders of Pregnancy in the North Indian Population. International Journal of Women's Health, 5, 101-108. https://doi.org/10.2147/IJWH.S40473

[23] Khan, A., Ghosh, A., Banerjee, P.K. and Mondal, T.K. (2014) Profile and Outcome of Eclampsia in a Rural Tertiary Hospital. International Journal of Recent Trends in 
Science and Technology, 10, 526-529.

[24] Lain, K.Y. and Roberts, J.M. (2002) Contemporary Concepts of the Pathogenesis and Management of Preeclampsia. JAMA, 287, 3183-3186.

https://doi.org/10.1001/jama.287.24.3183

[25] Odegard, R.A., Vatten, L.J., Nilsen, S.T., Salvesen, K.A. and Austgulen, R. (2000) Preeclampsia and Fetal Growth. Obstetrics \& Gynecology, 96, 950-955. https://doi.org/10.1097/00006250-200012000-00016

[26] Barker, D.J. (2004) The Developmental Origins of Well-Being. Philosophical Transactions of the Royal Society B: Biological Sciences, 359, 1359-1366. https://doi.org/10.1098/rstb.2004.1518

[27] Odell, C.D., Kotelchuck, M., Chetty, V.K., Fowler, J., Stubblefield, P.G., Orejuela, M. and Jack, B.W. (2006) Maternal Hypertension as a Risk Factor for Low Birth Weight Infants: Comparison of Haitian and African-American Women. Maternal and Child Health Journal, 10, 39-46. https://doi.org/10.1007/s10995-005-0026-2

[28] Williams, K.P. and Baldwin, V. (1998) The Effect of Ethnicity on the Development of Small for Gestational Age Infants Associated with Hypertension in Pregnancy. The American Journal of Perinatology, 15, 125-128. https://doi.org/10.1055/s-2007-993911

[29] Roberts, J.M. (1984) Pregnancy-Related Hypertension. Medicine-Principles and Practice. WB Saunders, Philadelphia, 703-752.

[30] Chesley, L.C. (1974) A Short History of Eclampsia. Obstetrics \& Gynecology, 43, 599-602.

[31] Chesley, L.C. (1978) Superimposed Preeclampsia or Eclampsia. In: Chesley, L.C., Ed., Hypertensive Disorders in Pregnancy, Appleton, New York, 14, 302, 482.

[32] Roberts, J.M. and Hubel, C.A. (1999) Is Oxidative Stress the Link in the Two-Stage Model of Preeclampsia? The Lancet, 354, 788-789.

https://doi.org/10.1016/S0140-6736(99)80002-6

[33] Steegers, E.A.P., von Dadelszen, P., Duvekot, J.J. and Pijnenborg, R. (2010) Pre-Eclampsia. The Lancet, 376, 631-644. https://doi.org/10.1016/S0140-6736(10)60279-6

[34] Roberts, J.M. and Gammill, H.S. (2005) Preeclampsia-Recent Insights. Hypertension, 46, 1243-1249. https://doi.org/10.1161/01.HYP.0000188408.49896.c5

[35] Pritchard, J.A. (1978) Management of Severe Preeclampsia and Eclampsia. Seminars in Perinatology, 2, 83.

[36] Sibai, B., Dekker, G. and Kupferminc, M. (2005) Pre-Eclampsia. The Lancet, 365, 785-799. https://doi.org/10.1016/S0140-6736(05)17987-2

[37] Roberts, C.L., Algert, C.S., Morris, J.M., Ford, J.B. and Henderson Smart, D.J. (2005) Hypertensive Disorders in Pregnancy: A Population-Based Study. Medical Journal of Australia, 182, 332-335. https://doi.org/10.5694/j.1326-5377.2005.tb06730.x

[38] Cnattingius, S., Reilly, M., Pawitan, Y. and Lichtenstein, P. (2004) Maternal and Fetal Genetic Factors Account for Most of Familial Aggregation of Pre-Eclampsia: A Population-Based Swedish Cohort Study. American Journal of Medical Genetics Part A, 130, 365-371. https://doi.org/10.1002/ajmg.a.30257

[39] Duckitt, K. and Harrington, D. (2005) Risk Factors for Pre-Eclampsia at Antenatal Booking. Systematic Review of Controlled Studies. BMJ, 330, 565. https://doi.org/10.1136/bmj.38380.674340.E0

[40] Hernandez Diaz, S., Toh, S. and Cnattingius, S. (2009) Risk of Pre-Eclampsia in 
First and Subsequent Pregnancies: Prospective Cohort Study. BMJ, 338, b2255. https://doi.org/10.1136/bmj.b2255

[41] Saftlas, A.F., Levine, R.J., Klebanoff, M.A., Martz, K.L., Ewell, M.G., Morris, C.D. and Sibai, B.M. (2003) Abortion, Changed Paternity, and Risk of Pre-Eclampsia in Nulliparous Women. American Journal of Epidemiology, 157, 1108-1114. https://doi.org/10.1093/aje/kwg101

[42] Skjaerven, R., Wilcox, A.J. and Lie, R.T. (2002) The Interval between Pregnancies and the Risk of Pre-Eclampsia. The New England Journal of Medicine, 346, 33-38. https://doi.org/10.1056/NEJMoa011379

[43] Roberts, J.M., Pearson, G., Cutler, J. and Lindheimer, M. (2003) Summary of the NHLBI Working Group on Research on Hypertension during Pregnancy. Hypertension, 41, 437-445. https://doi.org/10.1161/01.HYP.0000054981.03589.E9

[44] McDonald, S.D., Best, C. and Lam, K. (2009) The Recurrence Risk of Severe de Novo Pre-Eclampsia in Singleton Pregnancies: A Population-Based Cohort. BJOG, 116, 1578-1584. https://doi.org/10.1111/j.1471-0528.2009.02317.x

[45] Caritis, S., Sibai, B., Hauth, J., et al. (1998) Low-Dose Aspirin to Prevent Preeclampsia in Women at High Risk. The New England Journal of Medicine, 338, 701-705. https://doi.org/10.1056/NEJM199803123381101

[46] World Health Organization (1988) Geographic Variation in the Incidence of Hypertension in Pregnancy. World Health Organization International Collaborative Study of Hypertensive Disorders of Pregnancy. American Journal of Obstetrics and Gynecology, 158, 80-83. https://doi.org/10.1016/0002-9378(88)90782-X

[47] Gong, J., Savitz, D.A., Stein, C.R. and Engel, S.M. (2012) Maternal Ethnicity and Pre-Eclampsia in New York City, 1995-2003. Paediatric and Perinatal Epidemiology, 26, 45-52. https://doi.org/10.1111/j.1365-3016.2011.01222.x

[48] Caughey, A.B., Stotland, N.E., Washington, A.E. and Escobar, G.J. (2005) Maternal Ethnicity, Paternal Ethnicity, and Parental Ethnic Discordance: Predictors of Preeclampsia. Obstetrics \& Gynecology, 106, 156-161. https://doi.org/10.1097/01.AOG.0000164478.91731.06

[49] Urquia, M.L., et al. (2012) Serious Preeclampsia among Different Immigrant Groups. Journal of Obstetrics and Gynaecology Canada, 34, 348-352. https://doi.org/10.1016/S1701-2163(16)35215-X

[50] Bryant, A.S., Seely, E.W., Cohen, A. and Lieberman, E. (2005) Patterns of Pregnancy-Related Hypertension in Black and White Women. Hypertension in Pregnancy, 24, 281-290. https://doi.org/10.1080/10641950500281134

[51] Goodwin, A.A. and Mercer, B.M. (2005) Does Maternal Race or Ethnicity Affect the Expression of Severe Preeclampsia? American Journal of Obstetrics and Gynecology, 193, 973-978. https://doi.org/10.1016/j.ajog.2005.05.047

[52] Ghosh, G., Grewal, J., Männistö, T., Mendola, P., Chen, Z., Xie, Y.L. and Laughon, S.K. (2014) Racial/Ethnic Differences in Pregnancy-Related Hypertensive Disease in Nulliparous Women. Ethnicity \& Disease, 24, 283-289.

[53] World Health Organization (2003) Managing Complications in Pregnancy and Childbirth-A Guide for Midwives and Doctors. World Health Organization, Geneva, S-35-S-56.

[54] Pritchard, J.A., Cunningham, F.G. and Pritchard, S.A. (1984) The Parkland Memorial Hospital Protocol for Treatment of Eclampsia: Evaluation of 245 Cases. American Journal of Obstetrics and Gynecology, 148, 951-963. https://doi.org/10.1016/0002-9378(84)90538-6 
[55] Chesley, L.C. (1984) History and Epidemiology of Preeclampsia-Eclampsia. Clinical Obstetrics and Gynecology, 27, 801-820. https://doi.org/10.1097/00003081-198412000-00004

[56] Salas, S.P. (1999) What Causes Pre-Eclampsia? Best Practice \& Research Clinical Obstetrics \& Gynaecology, 13, 41-57. https://doi.org/10.1053/beog.1999.0005

[57] Abalos, E., Cuesta, C., Grosso, A.L., Chou, D. and Say, L. (2013) Global and Regional Estimates of Pre-Eclampsia and Eclampsia: A Systematic Review. European Journal of Obstetrics \& Gynecology and Reproductive Biology, 170, 1-7. https://doi.org/10.1016/j.ejogrb.2013.05.005

[58] Roberts, J.M. and Lain, K.Y. (2002) Recent Insights into the Pathogenesis of Pre-Eclampsia. Placenta, 23, 359-372. https://doi.org/10.1053/plac.2002.0819

[59] Wolf, M., Shah, A., Jimenez Kimble, R., Sauk, J., Ecker, J.L. and Thadhani, R. (2004) Differential Risk of Hypertensive Disorders of Pregnancy among Hispanic Women. Journal of the American Society of Nephrology, 15, 1330-1338. https://doi.org/10.1097/01.ASN.0000125615.35046.59

[60] Zwart, J.J., Richters, A., Öry, F., de Vries, J.I.P., Bloemenkamps, K.W.M. and van Roosmalen, J. (2008) Eclampsia in the Netherlands. Obstetrics \& Gynecology, 112, 820-827. https://doi.org/10.1097/AOG.0b013e3181875eb3

[61] Anderson, N.H., Sadler, L.C., Stewart, A.W., Fyfe, E.M., McCowan, L.M. and Aust, N.Z. (2012) Ethnicity, Body Mass Index and Risk of Pre-Eclampsia in a Multiethnic New Zealand Population. Journal of Obstetrics and Gynaecology, 52, 552-558. https://doi.org/10.1111/j.1479-828X.2012.01475.X

[62] Carr, A., Kershaw, T., Brown, H., Allen, T. and Small, M. (2013) Hypertensive Disease in Pregnancy: An Examination of Ethnic Differences and the Hispanic Paradox. Journal of Neonatal-Perinatal Medicine, 6, 11-15. https://doi.org/10.3233/NPM-1356111

[63] Urquia, M.L., Glazier, R.H., Gagnon, A.J., Mortensen, L.H., Nybo Andersen, A.M., Janevic, T., Guendelman, S., Thornton, D., Bolumar, F., Sanchez, I.R., Small, R., Davey, M.A., Hjern, A. and ROAM Collaboration (2014) Disparities in Pre-Eclampsia and Eclampsia among Immigrant Women Giving Birth in Six Industrialised Countries. BJOG, 121, 1492-1500. https://doi.org/10.1111/1471-0528.12758

[64] Naimy, Z., Grytten, J., Monkerud, L. and Eskild, A. (2015) The Prevalence of Pre-Eclampsia in Migrant Relative to Native Norwegian Women: A Population-Based Study. BJOG, 122, 859-865. https://doi.org/10.1111/1471-0528.12978

[65] Agrawal, S. and Walia, G.K. (2014) Prevalence and Risk Factors for Pre-Eclampsia in Indian Women: A National Cross Sectional Study. 2014 Annual Meeting Program, Boston, 1-3 May 2014, Poster Session 7.

[66] Xiao, J., Shen, F., Xue, Q., Chen, G., Zeng, K., Stone, P., Zhao, M. and Chen, Q. (2014) Is Ethnicity a Risk Factor for Developing Preeclampsia? An Analysis of the Prevalence of Preeclampsia in China. Journal of Human Hypertension, 28, 694-698. https://doi.org/10.1038/jhh.2013.148

[67] Knuist, M., Bonsel, G.J., Zondervan, H.A. and Treffers, P.E. (1998) Risk Factors for Preeclampsia in Nulliparous Women in Distinct Ethnic Groups: A Prospective Cohort Study. Obstetrics \& Gynecology, 92, 174-178. https://doi.org/10.1097/00006250-199808000-00004

[68] Rao, A.K., Daniels, K., El-Sayed, Y.Y., Moshesh, M.K. and Caughey, A.B. (2006) Perinatal Outcomes among Asian American and Pacific Islander Women. American Journal of Obstetrics and Gynecology, 195, 834-838. https://doi.org/10.1016/j.ajog.2006.06.079 
[69] Savitz, D.A., Danilack, V.A., Engel, S.M., Elston, B. and Lipkind, H.S. (2014) Descriptive Epidemiology of Chronic Hypertension, Gestational Hypertension, and Preeclampsia in New York State, 1995-2004. Maternal and Child Health Journal, 18, 829-838. https://doi.org/10.1007/s10995-013-1307-9

[70] Prasmusinto, D., Skrablin, S., Fimmers, R. and van der Ven, K. (2004) Ethnic Differences in the Association of Factor V Leiden Mutation and the C677T Methylenetetrahydrofolate Reductase Gene Polymorphism with Preeclampsia. European Journal of Obstetrics \& Gynecology and Reproductive Biology, 112, 162-169. https://doi.org/10.1016/S0301-2115(03)00314-2

[71] Williams, K.P. and Wilson, S. (1997) Ethnic Variation in the Incidence of HELLP Syndrome in a Hypertensive Pregnant Population. Journal of Perinatal Medicine, 25, 498-501. https://doi.org/10.1515/jpme.1997.25.6.498

[72] Fang, J., Madhavan, S. and Alderman, M.H. (1999) The Influence of Maternal Hypertension on Low Birth Weight: Differences among Ethnic Populations. Ethnicity \& Disease, 9, 369-376.

[73] Mbah, A.K., Alio, A.P., Marty, P.J., Bruder, K., Whiteman, V.E. and Salihu, H.M. (2010) Pre-Eclampsia in the First Pregnancy and Subsequent Risk of Stillbirth in black and White Gravidas. European Journal of Obstetrics \& Gynecology and Reproductive Biology, 149, 165-169. https://doi.org/10.1016/j.ejogrb.2009.12.035

[74] Chauhan, P., Chauhan, V.K.S. and Shrivastava, P. (2012) Maternal Mortality among Tribal Women at a Tertiary Level of Care in Bastar, Chhattisgarh. Global Journal of Health Science, 4, 132-141. https://doi.org/10.5539/gjhs.v4n2p132

[75] Lawoyn, T.O. and Ani, F. (1996) Epidemiologic Aspects of Pre-Eclampsia in Saudi Arabia. East African Medical Journal, 73, 404-406.

[76] Macay, A.P., Berg, C.J. and Atrash, H.K. (2001) Pregnancy-Related Mortality from Preeclampsia and Eclampsia. Obstetrics \& Gynecology, 97, 533-538. https://doi.org/10.1097/00006250-200104000-00011

[77] Tucker, M.J., Berg, C.J., Callaghan, W.M. and Hsia, J. (2007) The Black-White Disparity in Pregnancy-Related Mortality from 5 Conditions: Differences in Prevalence and Case-Fatality Rates. American Journal of Public Health, 97, 2. https://doi.org/10.2105/AJPH.2005.072975

[78] Lewis, G. (2007) The Confidential Enquiry into Maternal and Child Health (CEMACH). Saving Mothers' Lives: Reviewing Maternal Death to Make Motherhood Safer-2003-2005. The Seventh Report on Confidential Enquiries into Maternal Deaths in the United Kingdom. CEMACH, London. 